\title{
The Management of Operational Risk in the Microfinance Sector Looked through Albanian Reality
}

\author{
Alma Delija, PhD Cand \\ Agricultural University of Tirana / Albania \\ amadelija@gmail.com
}

Doi:10.5901/mjss.2015.v6n2s2p35

\begin{abstract}
The Albanian economy, as an economy of a developing country characterized by a positive trend upward despite the restraining effects caused by the global crisis. Macroeconomic indicators are demonstrating consistency, the financial system is healthy and economic activity making progress. At the same time, the diversification of the local economy to respond to the demands of the free market, increased competition, and untapped potential in agriculture necessitates the strengthening of relations and cooperation structures for financing sustainable development in the country. Experience has shown that microfinance has been a powerful tool for the development of small- and medium agribusiness, playing an ever more crucial in improving the living conditions and welfare of the population, especially in rural areas, the creation the creation of new work by contributing to the economic development of the country. The rapid growth of this sector is expected to continue as a result of increased funding needs, especially in rural areas. But this intensive growth has changed and risk profile microfinance institutions. These institutions looking constantly expanding, often did not pay sufficient attention to risks. One of these is and operational risk. Different authors give numerous definitions about operational risk, often with overlapping similar. This paper does not pretend to provide solutions to gold in relation to operational risk avoidance, but will be followed up in a structured form as suggested by theoretical analysis of this field study authors.
\end{abstract}

Keywords: Operational Risk; IMF; Risk; Risk Control; Credit Risk.

\section{Introduction}

Risk is an integral part of financial intermediation why risk management should be a key priority for microfinance as well as a challenge to be achieved in conditions of uncertainty. In the microfinance sector, systematic risk management is not yet in the right.

2012 and 2013 were relatively difficult for the Albanian economy affected most financial and economic activities of the country. Consequently, the banking sector is faced with a drop of his portfolio and a deterioration of quality indicators of borrowing in place.

In this context extremely challenging for financial organizations of micro-credit, had the objective to enhance the quality of their management of the existing portfolio to strengthen and improve further risk assessment and management of the loan portfolio.

This work is guided by two main purposes:

Firstly, the theoretical decomposition of the concept of operational risk and its management, particularly in microfinance institutions relying on modern literature in this area.

Secondly, the investigation of this phenomenon in the Albanian reality through practical illustration of a case study where I selected Albanian Savings and Credit Union as one of the leading microfinance institutions in Albania.

\section{Critical Review of the Literature}

The management of operational risk by most authors defined as a decision-making tool to help systematically identify operational risks and to determine the best courses of action for any given situation. Globalization and technological development have provided new opportunities for profit banking sector in general but at the same time has become more tangible operational risks (Bloom \& Galloway, 1999). It seems that risk control capabilities have not advanced at the same pace with these rapid developments. According to Williams (2000), the definition of operational risk depends on the nature and type of organization. Meanwhile, the author also stresses that the identification of risk, as the first step of the risk management process provides an important basis for the organization for the support towards the future. Two other 
authors, Crouhy and Mark (2000) find that an organization should analyze the causes and effects of an operational loss. A typical due to operational losses can mention human errors or inaccuracies. The effect of this risk could cause a financial loss, although this may be the final result of a chain of effects.

A summary of the cause-effect relation to each risk factor is given below:

Table 1. Causes and Effects

\begin{tabular}{lll} 
Risk Factor & Causes & Effects \\
\hline $\begin{array}{l}\text { Human } \\
\text { Resources }\end{array}$ & $\begin{array}{l}\text { Loss of key staff due to movements of } \\
\text { the staff to competitors }\end{array}$ & $\begin{array}{l}\text { Reduction of profits, increased recruitment and training } \\
\text { costs, disruption of existing staff }\end{array}$ \\
\hline Process & $\begin{array}{l}\text { Productivity outdated while the value } \\
\text { increases }\end{array}$ & $\begin{array}{l}\text { The difference in the costs of the process with the projected } \\
\text { (excluding malfunction of the process) }\end{array}$ \\
\hline Technology & Increased costs, increased demand & $\begin{array}{l}\text { The difference in operating costs of new technologies with } \\
\text { the projected }\end{array}$ \\
\hline
\end{tabular}

Crouhy \& Mark (2000)

Another author of the field, Laycock (1998) lists six categories of causes that can lead to operational risk dazzles us. Causes and operational risk events classified by Laycock given in Table 2.

Table 2. Causes and Events

\begin{tabular}{|c|c|}
\hline \multirow{8}{*}{$\begin{array}{l}\text { M Staff / Employees } \\
\text { Errors } \\
\text { Violation } \\
\text { Internal regulations } \\
\text { Employee Responsibility } \\
\text { Lack of key staff } \\
\text { Organizational structure } \\
\text { Wrong actions }\end{array}$} & $\stackrel{\leftrightarrow}{\Rightarrow}$ Technology \\
\hline & System failure \\
\hline & Inviolability of the system \\
\hline & System obsolescence \\
\hline & System adequacy \\
\hline & Compliance System \\
\hline & Risk Model, Data quality \\
\hline & $\Leftrightarrow$ Assets \\
\hline$\Leftrightarrow$ Relations with customers & Obstacle to business \\
\hline Suitability with customers & Loss / destruction of assets \\
\hline Capacity of clients & Third party Theft \\
\hline Power of customers & Fraud \\
\hline Money laundering & \\
\hline$\stackrel{M}{\rightarrow}$ Memos & $\stackrel{\leftrightarrow}{\rightarrow}$ Others \\
\hline$\sim \quad$ Legal risk & $\sim$ Project Risk \\
\hline$\sim$ Changes in regulatory standards & $\sim$ Reputational Risk \\
\hline
\end{tabular}

The risk is among the most discussed phenomena in today's world economy. Increasing the level of risk in financial activity is an inevitable process. He dictated the opening of the economy and the gradual integration into regional and global financial markets. Theorists claim that the connection with the acquisition risk is in most cases a straight connection, which means that looking for a higher profit entities should face a higher risk. While risk increases, organizations need to think about strategy and techniques that afford it. This means that all management be financial and economic units in developing their management strategies and throughout the process of decision-making for directing the activities of units should consider not only the existence of various types of risks that arise in financial markets but should have the necessary ability and professional. They need to diagnose the causes of birth of these risks and should possess the necessary instruments for taking the time appropriate measures to cope with these financial risks by eliminating their influence fully or partially on the results of economic activity direct financial units.

Often the negative consequences of risk offset or prevented by strengthening internal control mechanisms. A part of the requirements to meet the risk is even located in the necessary way through regulations and normative acts. This is true especially in the case of economic sectors of particular importance as banks and wider financial institutions.

What is the financial risk?

Risk is uncertainty or probability that something bad will happen. That something bad in financial terms translates loss. Financial risk is conceived as a negative influence on the outcome of the entity because of some uncertainties financial nature. 
Operational risk is the risk of negative effects on financial performance and capital of the bank caused by negligence at work of employees, procedures and inadequate internal processes, inadequate management information systems and external events unpredicted.

In some other literature operational risk is defined as the organization's exposure to potential losses as a result of lack or failure to properly execute its operations. These losses may be incurred as a result of failure or lack of internal employees, processes and systems and their inability to cope with the adverse effects of external factors. According Rachlin (1998), the operational risk factors than people, processes, and systems should take into account the external environment. These include criminal actions, legal risks, risks from third parties, etc. According to the same author, management practices available to reduce operational risk, can be divided into three categories:

Reduction of risk - management should diminish risk in products and processes;

Risk Control - to consider ways to control risk

Limiting risk - appropriate precautionary arrangements.

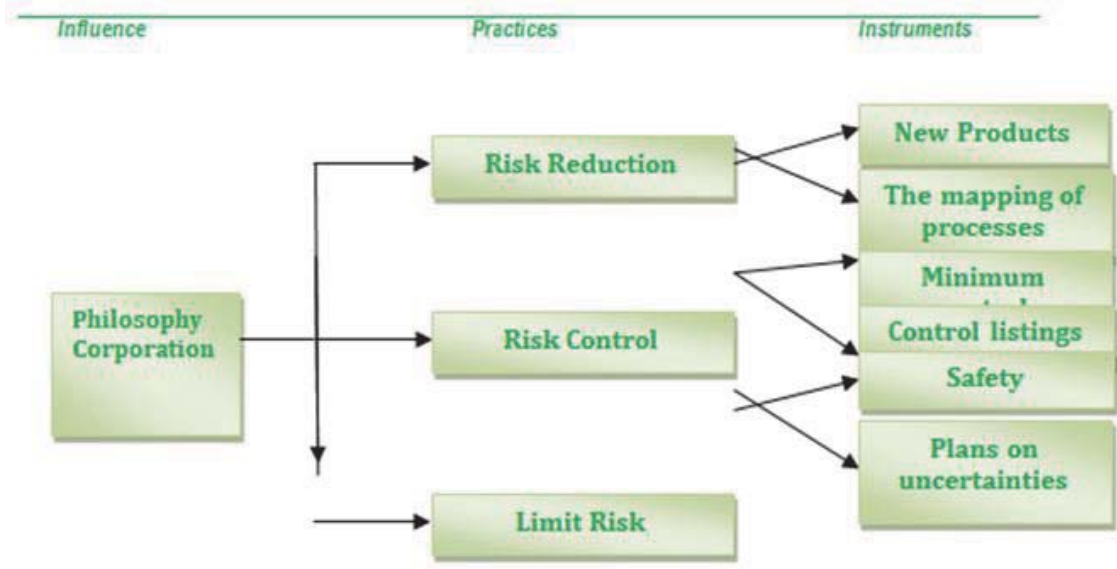

Figure 1. Practices operational risk management Rachlin (1998)

The authors Schwartz and Smith (1997), propose a structure with three columns, for the construction of a function effective operational risk management properly set policies, methodologies and infrastructure. Methodologies refer to the appropriate application of analytical models to measure operational risk, while explaining the structure of the control policies designed to ensure the existence, completeness, accuracy for all actions through proper separation of duties. They emphasize that have efficient infrastructure in order to make use of policies and methodologies.

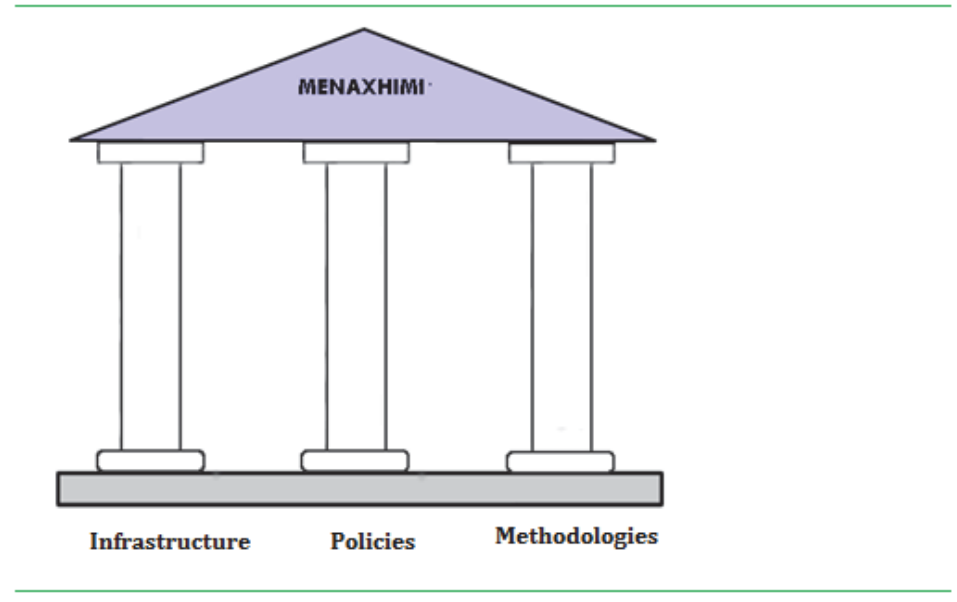

Figure 2. The three pillars of operational risk management, Schwartz \& Smith (1997) 
As noted in the literature, it is evident that operational risk management is an important subject that requires attention in the banking and microfinance sector in particular. Most authors emphasize that the main exposures to a decline or bankruptcy of the company may come as a result of human resources, processes, systems and external factors. Downstream operations management, should provide in-depth and timely response to the need to protect the organization's network from significant financial losses or in case of occurrence of adverse events.

Operational risk in microfinance institutions includes vulnerabilities facing a microfinance institution (MFI) in its daily operations that may result to the loss of its assets. At its core, operational risk is a concern that an MFI will lose its money through bad credit, fraud and theft. The following describes the controls and monitoring activities to reduce three types of operational risks (Table 3 ).

Table 3. Types of operational risk

\begin{tabular}{ccc} 
Type of risk & Type of loss & Source of loss \\
\hline Credit risk & The poor quality of the portfolio & Customers \\
The risk of fraud & Loss of fraud & Staff \\
Insurance risk & Loss by theft & External \\
\hline Churchill \& Coster (2001) & &
\end{tabular}

To reduce vulnerability to operational risks, microfinance institutions shape policies and procedures that make up the core of the system of internal control organization. These checks usually include preventative and investigative aspects. Preventive controls are used to prevent the occurrence of undesirable events. Examples of preventive controls include:

Hiring reliable employees who can make good decisions credit;

Ensure that loans are backed by collateral eligible;

Clear definition of duties of staff to prevent deliberate violation;

Authorization required to use resources to prevent the use of their inadequacy;

Reporting, keeping proper records procedures and records to prevent transactions 'improper' for profit;

Installation of sufficient security measures (guards, safes) to protect their assets.

To achieve the best possible preventive controls and investigative judgment is necessary. Preventive controls avoid problems before they occur, but investigative controls are generally easy to implement. For example, it is easier to make monthly bank reconciliations how to prevent the employees from the acquisition of payment. There are also important implications associated with the cost to be taken into consideration.

Microfinance institutions can not eliminate losses due to operational risks. Some loans are meant to go bad. Controls designed to minimize losses from operational risks should be carefully analyzed to assess their costeffectiveness of this because some controls can be more expensive than the value that they have.

\section{Organization of Microfinance Institutions (Case ASC Union)}

\subsection{ASC Union recognition and its mission}

Albanian Savings and Credit Union is a voluntary union of Savings and Credit Associations (SCA), established on 25 January 2002 on the basis of the Law on Savings and Credit Societies and licensed by the Bank of Albania. ASC Union is the product of the first microfinance program in Albania. Inspired by the cooperative financial models, ASC Union is based on Savings and Credit Societies, which have strong social roots in local communities. ASC Union clients are residents of rural areas who are also members of Savings and Credit Societies operating in that area.

ASC Union mission is to support financially and technically Savings and Credit Societies, which are financial institutions of the village, established and managed by the members and whose objective is the promotion of productive activities in rural areas.

\subsection{The legal framework and some definitions}

The activity of the institution conducted in accordance with Law no. 8782, dt. 03.05 .2001 "On Savings and Credit Societies" and Licensing issued by the Bank of Albania. Under the law loan savings are self-controllable and selfmanagement by members. Assembly members elect a Board of Directors and Supervisory Committee.

- Savings and Credit Associations (SCAs) are legal entities consisting of voluntary unions of individuals, natural 
or legal persons who deposit their money in society, first used by the company to grant credit to society members. In late 2013, the network results in 98 districts of ASC Union member.

- "Members of the savings and loan" are individuals, natural or legal persons who wish to deposit their savings and borrow through society and to accept the bylaws approved by the Savings and Credit Society. Currently, the network consists of 36.090 SCA member (Annual Report 2013 ASC Union).

- 'Contribution' is the amount paid in capital of an SCA or the Union by any person becomes a member of a SCA or member SCAs Union, at the time of affiliation.

\subsection{Institutional Developments over the years and Governing Bodies}

It is now known as ASC Union was born from a World Bank pilot project for rural poverty alleviation. Cash loans were given in Gjinar, mountainous area of Elbasan. Gradual development over the years brought increased demand from local residents for loans of this type. After the first areas of intervention, the project was expanded to new areas, and hence took the track and was developed Loan funds as a harbinger of Village Savings and Credit Societies operating in the country today. SCA Union emerged as a necessity to support financially and professionally SCAs, since their nature are small societies with limited managerial capacity.

Table 4: Institutional Developments in years

\begin{tabular}{|l|l|l|l|l|l|}
\hline & 1992 & $1993-1995$ & $1995-1999$ & $1999-2005$ & 2005-and on \\
\hline Central Structure & $\begin{array}{l}\text { World Bank } \\
\text { Pilot } \\
\text { Project }\end{array}$ & $\begin{array}{l}\text { Rural } \\
\text { Development } \\
\text { Fund }\end{array}$ & $\begin{array}{l}\text { Albanian } \\
\text { Development } \\
\text { Fund }\end{array}$ & $\begin{array}{l}\text { Rural Development } \\
\text { Fund }\end{array}$ & $\begin{array}{l}\text { Albanian Savings and Credit } \\
\text { Union }\end{array}$ \\
\hline Structure Field-Branches & & $\begin{array}{l}\text { Rural Credit } \\
\text { Fund }\end{array}$ & $\begin{array}{l}\text { Rural Credit Fund } \\
\text { (Association Rural } \\
\text { Development') }\end{array}$ & $\begin{array}{l}\text { Savings and credit } \\
\text { societies }\end{array}$ & Savings and credit societies \\
\hline Legal support & & Civil Code & Civil Code & Civil Code & Civil Code/Bank of Albania \\
\hline
\end{tabular}

Under the law "On Savings and Credit and their unions' governing bodies of the Union / SCA are:

General Assembly

Board of Directors

Supervisory Committee

The General Assembly is the decision making body. It is convened once a year by the Management Board or the Supervisory Committee.

The Board of Directors of Union / districts elected by secret ballot by the General Assembly of the Union, from the members of savings and credit societies. He is the executive body of the Union / districts and consists of no fewer than three persons, for a period determined in-laws. The Board of Directors elects its chairman and vice chairman.

Supervisory Committee of the Union / SCA is monitoring body for financial and administrative operations of the Union / districts. His object, under the statute of SCA is to oversee all financial operations carried out, to ensure that the Board of Directors to make decisions under the statute and by the decisions of the General Assembly, and to evaluate the actions of the Board of Directors risk.

\subsection{Market share and scope of activity}

ASC Union credit applies a methodology based on group and individual. Underlying methodology ASC Union is lending through savings and credit society. So, for an individual to apply or get a loan should become or be a member of a group of licensed and specifically, a member of a Joint Savings and Loan, to the ASC Union methodology is based on the principles of operation of Financial Cooperative. Albanian Savings and Credit Union works in 16 districts: Tirana, Durres, Elbasan, Peqin, Gramsh, Lushnje, Fier, Berat, Vlora, Saranda, Shkodra, Malesia e Madhe, Kuçova, Pogradec.

ASC Union is committed to and has worked intensively to extend the zone of intervention as one of the main objectives of its activity in 2013. During the third quarter, was undertaken feasibility study process for intervention in a new circle (of Lezha) and specifically in 7 villages in Dajç's commune. In fulfillment of the goals for expanding the scale of intervention during 2014, ASC Union aims expanding network of SCAs as Përmeti and Korca district, areas which possess strong potential for development of the farm, and districts will to create more opportunities of this area farmers to 
finance their productive activities. On 12/31/2013, Union SCA's Group results in 98 affiliated, operating in 1,080 villages in 17 districts with a total of 36.090 members in the network SCAs.

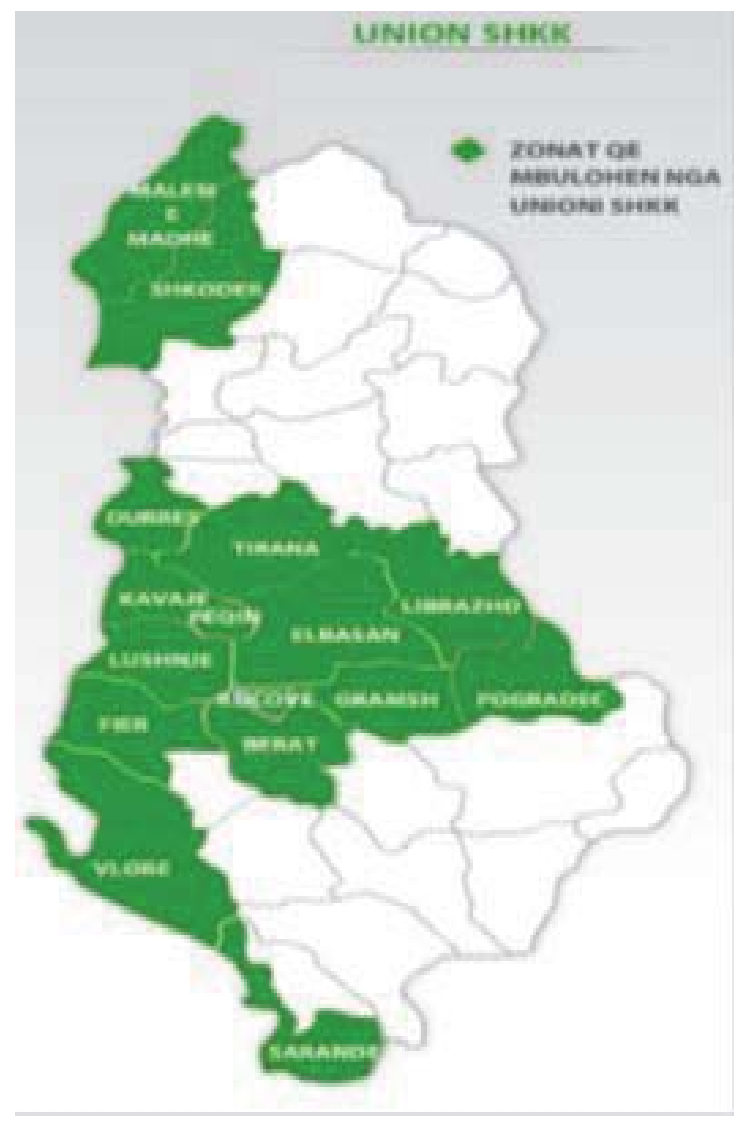

\subsection{Microfinance sector and market positioning of ASC Union}

In late 2013 ASC Union turns out to be a stretch in 17 districts with 13 regional offices supported by central office. The focus of the institution is a very specific market: financial services in rural areas served little or no other financial institutions. Other facilities like NOA or ProCredit Bank are trying to penetrate into rural areas with their services but their presence remains limited. This situation differs from rural to urban and semi-urban areas where the pressure of competition between financial institutions is greater through institutions such as NOA, BESA, ProCredit Bank and Intesa Sanpaolo lately. Competition is strong especially for SME loans and the expansion of SCAs in Tirana and more urbanized villages. We emphasize the fact that the rural market at large financial services not covered by traditional banks are not willing to lend to private small entrepreneurs in these areas.

Savings and Credit Union and the network of SCAs rely on these competitive advantages to differentiate from other institutions to micro-lending in rural areas:

(:) lower interest on loans, combined with higher interest savings;

(:) extensive experience in services in the rural sector and long-term relationships with villages;

(:) work on a voluntary basis in the network of nearly 800 elected members of the SCA, allowing to be closer to the customer;

(): support members with technical assistance.

- In competitive disadvantages can mention:

(:) Compared with banks, there is room for improvement in terms of creating a name known to attract depositors (Union marketing and financial products it offers);

: rigidity of interest rates applied to financial products;

(2) number of relatively limited services. 


\section{Operational Risk Faced Microfinance Institutions (Case ASC Union)}

Microfinance industry has grown rapidly in scope over the last decade. The rapid growth of this sector is expected to continue as a result of increased funding needs, especially in rural areas. But this intensive growth has changed and risk profile microfinance institutions. These institutions constantly seeking expansion of their financial activity, often do not pay proper attention risks, where one of them is operational risk. Different authors provide numerous definitions about operational risk, but concisely operational risk can be defined as the possibility that subjects suffer financial loss as a result of ineligible or failed internal processes, systems, human errors or adverse events. Need for recognition of operational risk and its management procedures, MFIs must look like a rather important internal functions of management lines.

\subsection{Credit Risk}

Credit risk, leading to serious weaknesses a microfinance institution, and consists in the deterioration of the quality of the loan portfolio resulting in credit losses and higher costs of management violations. The loan portfolio is the main item in the statement of financial position ASC Union. A special attention during 2013 was paid careful management of the loan portfolio, increasing the volume of lending and maintaining credit quality. Although given around 5,000 new loans to finance agricultural activities (greenhouses, vegetables, vines, fruit trees, olive trees), livestock (bovine breeding, petty, pigs, poultry), trade and services (agricultural inputs, commercial premises, machinery agricultural, transportation, commodity turnover), the loan portfolio in the SCA found to have a stagnant during 2013. Among the factors that have contributed to distinguish the effects of the economic crisis, credit tightening measures, campaigns in rural areas, adverse weather beginning of the year etc. In the process of lending, the priority of the Union remains the proper selection of the client, his moral evaluation, recognition by the Board to his reputation and other features located in the internal regulations of districts.

$\sim$ Maintaining the quality of the loan portfolio. A good quality loan portfolio constitutes a solid basis for sustainability and stability of the institution in continuity. As such, protecting the quality of the portfolio should always be at the core of ASC Union. Continuous monitoring and control his will ensure acceptable levels of risk, and taking appropriate measures to improve problems in any particular SCA or about. Among the measures to be taken to keep control of credit risk and improve the quality of the portfolio can mention:

$\sim$ Careful selection of borrower clients;

Financial depth analysis of the activities funded by loans;

$\sim$ Functioning of the task force groups by ASC Union to support some SCAs that present difficulties and problems of localized mainly in Tirana and Shkodra;

$\sim$ Contracting execution companies licensed to collect loans.

\subsection{Credit risk control}

Management of credit risk can be divided into preventive measures taken by the lenders before granting a loan and the use of incentives and penalties after giving credit to encourage timely repayment of the loan. Before the disbursement of a loan, a lender reduces credit risk through controls that reduce the potential for loss, such as the preliminary evaluation in bringing the document required time, financial analysis of the client's income by lending specialist in inspections necessary in the business center to review the investment plan. Once a loan is disbursed, a lender for risk management procedures extends through continuous controls that reduce the potential for loss to controls that reduce actual losses. As such, the procedures of credit risk management is a key component for MFIs. Four key controls credit risk:
* Loan product design;
* Review of the client;
* Credit Union Committee of SCA;
- Credit Monitoring and management of violations. 
Figure 3. Reduce credit risk through product design

\begin{tabular}{ll}
\hline Requests Eligibility & $\begin{array}{l}\text { Many MFls require that applicants meet certain criteria which are known as reducing credit } \\
\text { risk. For lending to small entrepreneurs, expected to have a commitment to their business } \\
\text { experience (minimum } 6 \text { months). Other requirements include documentation necessary } \\
\text { adaptability of business, throughput books, bills paid taxes etc.) and a business plan. }\end{array}$ \\
\hline Amounts loan & $\begin{array}{l}\text { Should ensure that the loan amount is within the capacity of the client to repay. One product } \\
\text { design mistakes is to increase the size of the loan. The second issue, although less common, } \\
\text { is issuing multiple loans where the customer has credit from multiple sources), being } \\
\text { overcome client's ability to repay. }\end{array}$ \\
\hline One way to address the issue of capacity is to extend the term of the loan by making small \\
installments. This approach, however, must be balanced with the fact that the possibility for \\
another loan is a primary incentive loan repayment. If the prospect of a loan else is too far, \\
some clients may lose an important incentive to continue repaying this loan.
\end{tabular}

\subsection{Examination of customers}

An important element of limiting credit risk of customers includes examining, on specific analysis is needed to ensure that they have the willingness and ability to pay for a regular loan repayment. When analyzing the customers credit, microfinance institutions usually use the technique of five C-s (character, collateral, capacity, conditions, capital). If any of these components is poorly analyzed, credit risk increases. To limit this risk, institutions develop policies and procedures to analyze each component.

- Character -an indication of the applicant's readiness to repay the loan and the ability to run the business.

- Capacity - If the family business cash flow could afford the repayment of the loan. To assess the applicant's capacity to repay the loan, loan officers perform assessments for business.

- Capital - assets and liabilities of the business or family. This allows the loan officer to determine whether the business is viable and how much capital already invested in the business.

- Collateral - Access to an asset that the applicant is willing to give up on the failure.

- Conditions - A business plan that considers the level of competition and the market for the product or service, legal and economic environment.

\subsection{Monitoring of credit risk and financial indicators ASC Union}

To monitor the quality of the loan portfolio, it is recommended that the lending entity to monitor the quality of the portfolio according to reports on a monthly basis. These include the risk of loan, credit report lost (writte-off) and the ratio of provisions. In addition an important subject is monitoring the number and value of loans rescheduled (restructured).

- Portfolio at risk: This report should be used primarily as an indicator for monitoring the quality of the portfolio.

- Lost credit report (writte-off): This report shows the degree of unrecoverable loans during the last period.

- Provisions Report: Shows the adequacy of reserves in relation to the portfolio.

- The ratio of restructured loans: Shows the extent of loans that were rescheduled in the last period.

For reasons microcredit financing, microfinance portfolios are not typically exposed to concentration risk as traditional big banks, where individual loans do not represent a significant part of the portfolio. However, microfinance institutions should monitor their loan portfolio composition, quality, areas of operation, business sector etc. 
A special role in monitoring the credit risk of the risk plays sector, where its activity is concentrated mainly in credit risk management, consistently enforcement field verification procedures, implementation of set standards and verification credit facility. Part of credit risk management are the identification, measurement, monitoring and reporting of risks to which the Union and the SCAs are exposed.

The process of credit risk assessment included evaluation CAMEL network method, the assessment of SCA in the process of lending by the Union as asset quality, capital adequacy, earnings, liquidity and KCS management and monitoring borrowers. The focus of risk management is the completion and analysis of collateral placed as security for loans granted by the Credit Committee at the district level and the Union. Assessing network and comparative statistical evaluation SCAs and districts with common characteristics performed each quarter for credit risk situation, evaluate and trend of total credit risk to the whole organization and for certain categories according to the type of activities (agriculture, livestock, trade, services, etc.) and by branches of the districts in order to take appropriate measures.

Table 5: Rating ASC Union

\begin{tabular}{|c|l|c|c|}
\hline \multicolumn{2}{|c|}{ Rating ASC Union/ 31.12.2013 } & \multirow{2}{*}{ STANDARD } & \multirow{2}{*}{ ACCOMPLISHMENT } \\
\cline { 1 - 2 } I & RATE OF ASSESSMENT & 21 & 12 \\
\hline II & Capital Adequacy & 15 & 13 \\
\hline III & Income & 24 & 20 \\
\hline IV & Liquidity & 17 & 17 \\
\hline V & Management & 23 & 23 \\
\hline X & The total amount of points & 100 & 84 \\
\hline
\end{tabular}

The table shows that the network SCA evaluated 84 points and classified in the "Administer very good" (82-91 points).

$\sim$ Asset Quality assessed with 12 of the 21 points which is the standard. In this group recorded decline in index points PAR's report and deposit him in SCA to total assets.

$\sim$ Capital adequacy assessed with 13 of 15 points which is the standard. In this assessment affects the indicator of equity to fixed assets that appear satisfactory compared to other indicators of the group. However, capital adequacy continues to impact positively on the development and normal functioning of SCA network being one of its strengths.

$\sim$ Revenue assessed 20 out of 24 points which is the standard. The three indicators that constitute the revenue as percentage of income from portfolio loans to average total income to total average assets, and net financial margin to total average assets valued at maximum limits of the standard set.

Liquidity evaluated all of the standard points, 17 points. The two indicators that make up liquidity, as the ratio of current account deposits Union to SCA, loans over 5 years as $100 \%$ of the total long-term liabilities, estimated the upper limit of the standard set. Liquidity indicator pursuant to Regulation Supervision Bank of Albania shows consistency.

Management assessed with standard maximum score, 23 points, where management indicators liquidity condition in the coffers and bank accounts SCA network and Union, deposit portfolio growth, high level of receivables write-offs balance (writte-off) and \% satisfactory returns on loans loan installment affecting achievement of this standard.

As shown by the indicators taken into consideration results in ASC Union and the network of SCAs are organically related, not only in legal perspective oversight and audit functions, but also in view of institutional support, managerial, financial and administrative. ASC Union's strategy and policies pursued is in full support of the SCA network, facing numerous risks that arise in the development of network activity ASC Union thanks ability to maintain its financial viability expressed in indicators of the degree of intervention and those financial.

All microfinance institutions have had the experience of fraud carried out by members or individuals representing financial activity credit savings. Wherever there is money, there is the possibility of fraud. Microfinance institutions should not assume they can completely eliminate fraud. However, through proper controls they could significantly reduce this aspect.

\section{Management of Credit Risk in Albania}

In Albania credit risk management realized based on regulations issued by the Bank of Albania and its Oversight Council. 
The purpose of credit risk management by banks is to minimize possible losses from loans and other assets related to them and sensitive to movements in interest rates. This regulation defines the criteria, categories and methods of classification of loans and other assets of the bank to calculate an appropriate level of reserves to cover potential losses from the impossibility of restoring their full value.

\subsection{Credit rating}

Banks classify their loans in one of the following five categories:

1. Standard loans,

2. Credits in pursuit,

3. Substandard,

4. Doubtful

5. Credits lost.

Category 1 represents the highest quality of credit, while category 5 , represents the lower quality of the loan.

Loans classified in categories 1 and 2, constitute the quality loans. Loans classified in categories 3, 4, 5 constitute the "bad loans".

In the same category with the loan (principal and interest) that is classified, classified other accounts associated with it, which represent loans given by banks to people associated and dependent financially by the lender.

Supervision Department of the Bank of Albania has the right to request the amendment of the credit rating category when:

- judged that the interpretation of the above criteria by the banks is not fair;

- judged that other elements in addition to the above characteristics that justify changing the classification category.

\subsection{General requirements for the quality control of the credit portfolio}

Banks approve the Board, policies, procedures and internal rules for monitoring and control consistently quality of loan portfolio and other assets of the bank. These should include at least:

a. Lending strategy by periods, including realistic goals about expanding loan portfolio, its composition by sector, geography, currency, type of loan, etc.;

b. Policy interest rates, terms, repayment and loan amount;

c. Established rules for recognition and analysis of the borrower and/or credit of the guarantor;

d. Procedures for documentation needed to be met for the granting of loans, as well as credit approval, according to the hierarchy. Bank takes measures analysis processes and loan approval to be separated, to ensure control and quality in the decision, as well as sets the structure for credit monitoring in line with the size and diversity of lending activity;

e. Risk management policies for the entire portfolio and for each client in particular, lines of credit to a customer credit concentration by sector, monitoring under the credit facility and type, sensitive analysis of variances between credit portfolio and funding sources his regarding the terms and currency type, in terms of assessing the relationship between credit risk and other risks (exchange rate changes, interest rate changes, etc.);

f. Procedures on the ongoing progress of loans and their identification by groups of loans with similar characteristics, for tracking priority loans, continuous reevaluation of guarantees or collateral as well as for assessing the adequacy of provisions for potential loan losses.

Banks have as their aim not only continuously assess the quality of loan portfolio and other assets, but also the risk assessment of the impairment loss as their resulte.

\section{Rates of Reserve Funds to Cover Loan Losses}

Depending on the classification of loans, banks establish reserve funds to cover potential losses from loans. Rates of calculating provisions are:

A. The fixed rate for the group of quality loans:

1- For "standard loan" rate is 1 percent.

2- To "chase credit" rate is 5 percent.

Provisions for loans above calculated on the common value of principal and interest and are considered provisions 
to cover the statistical risk.

B. Variable rate for the group of non-performing loans:

- The principal:

3- "Substandard loans" not less than 20 percent;

4- "Credit questionable" not less than 50 percent;

5- "Loan loss" not less than 100 percent.

- The interest rate is 100 per cent in each case.

The provisions calculated for loans considered provisions to cover the risk of impairment of loans.

As a result, the Board of Directors of each bank periodically, but not less than once a year:

a. Review the strategies, policies and regulations of the bank for lending and credit risk management, in line with changes in market conditions and the rules of supervision,

b. Analyzes and evaluates especially the implementation of strategies, policies and actions of the bank on lending and its risk management, including the risks of lending in foreign currency (foreign currency) and/or indexed in foreign currency (currency foreign).

\section{Necessity of New Methods for Credit Risk Management}

Over the past few years noted that technology and new ideas have emerged from the financial engineering professionals who increasingly are applying their skills to build new models of credit risk analysis. The question is: Why now? There are at least seven reasons for this sudden wave of interest.

1. Increase the number of bankruptcies of financial institutions: In the context of increasing global competition, the number of bankruptcies has increased. It has that attention to credit risk increases even more by giving more weight to the risk analysis.

2. Margin more competitive: Almost paradoxically, despite the weakening of credit quality, interest margin and spreads have become lower. In short, risk return curve is deteriorating. Can you mention a few reasons, but the most important factor has been the increased competition for borrowers with lower quality, mainly by financial companies.

3. Values of volatile weak collateral: Previous banking crises have market, as crucial to property values or real assets are very difficult to predict how much more to return to liquidity. This constitutes the largest uncertainty in the lending process. Current issues about global inflation, have stressed the importance of welldetermination the value of real assets such as property and for other physical assets.

4. Increased off-balance sheet derivatives: Increased exposure to loans due to a strong expansion of the derivatives market has increased the need of credit analysis. This increase in credit risk was one of the major reasons for the introduction of the Bank for International Settlements capital requirements by banks in 1993. Based on the system of the Bank for International Settlements (BIS), banks must maintain a level certain of their capital to cover the market value of derivatives contracts OTC (over the counter) plus an additional capital for potential exposures Future contracts therefore reserves to cover losses from loans not return in time.

5. Technology: Advances in computer systems and information technology, such as the development in the credit database, has given banks and other financial institutions the opportunity to test their models and techniques for measuring and managing credit risk and the ability to modeling techniques proved more powerful and safe.

6. Capital requirements set by BIS: Notwithstanding the above reasons, the main purpose of banks to develop new models of credit risk management has been discontent with the imposition of BIS and central banks after 1992 for capital requirements for loans. Politics Today the BIS described as "a move that fits all". Under this policy all loans are subject to a fixed rate of $8 \%$ of the capital, this rate independent of the size of the loan, its maturity and most importantly independent of the quality of the borrower. In this way, loans granted to firms close to bankruptcy treated the same as those issued to a borrower AAA class, described as trustee bank borrower. For more current requirements for additional capital is above all loans, not allowed a lower demand for capital due to a higher degree of diversification of the loan portfolio.

7. Stress testing: These tests designed properly, can provide information that typical statistical models can be omitted, for example, deviations or abnormal movements of the market, extension of periods of market risk or structural market changes. Stress testing can serve as complementary tools for measuring other risks. For banks and other financial institutions, it is important to conduct stress tests in some markets, while some clients can achieve their financial activities in more than one market, and their inability to settle the obligation 
can be seen in any of them. According to the governor of the Fed, effectively use stress testing can be very profitable for banks. For example, based on the results of stress tests, banks can ensure their participation in some markets and can exercise more attention calculating potential risks to better protect themselves during periods of market crises. Given the additional risks that reveal stress tests, one of the first things that banks can do is increase their internal needs for capital to these activities.

Among the factors that currently protect the Albanian financial system from adverse developments in international financial markets, mention:

- Exposure quite limited and the direct and indirect Albanian financial institutions, particularly banks, other institutions and financial products, whose value is negatively impacted by the liquidity in international financial markets;

- Good financial performance in recent years of financial institutions and the European banking groups, which has created a sound financial protection through the creation of necessary reserves and buoyant business capitalization to absorb such shocks.

On the other hand, the prolonged and possible deterioration of the situation in international financial markets may have a reduced impact on the Albanian financial market through several directions, where we distinguish:

- Worsening of risk characteristics that carries lending quick and especially the currency, as a result of increased exchange rate volatility and the frequent change of interest rates. These are two important factors that can determine the solvency of borrowers in the case of foreign currency loans. Bank of Albania will pass several regulatory measures, which aim to mitigate this risk for banks and their customers and show that it is important Pee economic agents to finance development needs in the same currency in which secure income them;

- Exposure of the financial system to sectors of the economy that are negatively impacted by the decline of regional and global economy;

- The combination of difficulties in international financial markets with the unfavorable dynamics of the prices of energy and raw materials to food products on a global scale.

Insufficiency of financial market development, can serve as a natural defense mechanism against transmission of financial difficulties among different market segments and in relations with international financial markets, but this effect will be temporary. Within the above developments and referring to the banking sector, emphasizing the requirement for commercial banks' governing structures generally follow market developments closely, strengthen control systems in their institutions to take action to better diversify financial resources and their investment directions, develop a consistently well-capitalized activity and continuously monitor its risks. Bank of Albania should strengthen measures to enrich and implement the regulatory framework in terms of overall improvement of risk assessment systems in commercial banks, and should cooperate with the Financial Supervisory Authority to promote the full implementation of these principles in the rest of the financial market.

\section{Conclusions}

Operational risk cannot be avoided. This 'hidden risk' can be controlled, measured and provision by financial intermediaries.

[1] Line management actions need to provide in-depth and timely response to the need to protect the organization's network from significant financial losses as well as maintaining the potential penalty in case of occurrence of adverse events.

[D] Client careful selection of borrowers by management boards loan specialists should be the focus of the analysis of credit to guarantee a good performance of loan repayment.

[D] The expansion of the area of intervention credit savings versus maintaining quality loan portfolio.

[D] The loan disbursement process, should be paid a great attention to strictly follow the use of credit, to ensure that it goes to the destination stated in the credit analysis.

[D] The performance of banks or other financial institutions is closely linked to the process of credit risk management. This is because lending is one of the main activities not only for banks, but also serves as a stimulus to economic development. For this it is important forecasting and accurate measurement of credit risk.

[D] The business environment is constantly changing and every new day can appear threats and vulnerabilities. For this reason risk management process should be a process that is repeated to infinity. The choice of countermeasures that will be used to manage risk, should be put in balance with productivity, cost and 
efficiency of these measures. Therefore, risk management should be more of a managerial function than a technical function of banking activity.

[1] Taking into account developments in global financial markets and their impact on our market, especially those last months of the year supervisory authorities have undertaken changes in the regulations on "Credit Risk Management" to improve the lending process starting from borrowing capacity analysis to the correct classification of the loan portfolio. These changes serve to strengthen the continuity of the measures taken by the supervisory authority to minimize the risk of lending.

\section{Recommendations}

$\Leftrightarrow$ In order to increase the effectiveness of microfinance institutions plays an important role further improvement of network and computer programs in SCA offices which would provide real-time tracking of all financial transactions.

$\Leftrightarrow$ Cultivation and dissemination of organizational culture on operational risk and intolerant attitude towards him.

$\Leftrightarrow$ The completion of the full documentation and credit of members in full compliance with regulations and operating procedures of a SCA.

\section{References}

(GARP), g. A. Credit Risk Management.

Ammann, m. (2001). Credit Risk Valuation: Methods, and Models Applications.

Churchill, c. (2001). Microfinance Handbook Manangement Risk.

D Duffin, k. S. (2009). Credit Risk: Pricing, Measurement, and Management.

G Loeffler, p. P. (2011). Credit Risk and Modeling using Excel Vba.

Wish jc, g. G. (2005). On the Equivalence of the Kmv and Methods for Structural Likelihood Maximum Credit Risk Models.

Ledgerwood, j. (1999). "Microfinance Handbook: An Institutional and Financial Perspective".

M Crouhy, d. G. (2000). A Comparative Analysis Credit Risk of Current Models.

M Zeller, r. M. (2002). The Triangle of Microfinance: Financial Sustainability, Outreach, and Imact.

Mark, c. \&. (1998). "Key Steps in Building Consistent and Operational Risk Management Measurement, in Operational Risk and Financial Institutions".

R frey, a. M. (2002). Expected Dna Var Portfolio Shortfall in Credit Risk of Dependent.

Siddiqi, n. (2005). Credit Risk Scorecards: Developing Intelligent Implementing and Credit Scoring.

Tw dichter, m. H. (2007). What's Wrong with Microfinance? Action Ppractical Publishing, Rugby.

Kcs Lending Regulations Member Savings and Credit

Newsletters, Annual Reports 2005-2013 (Albanian Savings and Credit Union)

Annual Reports of the Bank of Albania 
